\title{
Association of Biosecurity and Hygiene Practices with Environmental Contamination with Influenza A Viruses in Live Bird Markets, Bangladesh
}

\author{
Sukanta Chowdhury, Eduardo Azziz-Baumgartner, James C. Kile, Md. A. Hoque, \\ Mohammed Z. Rahman, Md. E. Hossain, Probir K. Ghosh, Syed S.U. Ahmed, \\ Erin D. Kennedy, Katharine Sturm-Ramirez, Emily S. Gurley
}

\begin{abstract}
In Bangladesh, live bird market environments are frequently contaminated with avian influenza viruses. Shoplevel biosecurity practices might increase risk for environmental contamination. We sought to determine which shop-level biosecurity practices were associated with environmental contamination. We surveyed 800 poultry shops to describe biosecurity practices and collect environmental samples. Samples from $205(26 \%)$ shops were positive for influenza A viral RNA, $108(14 \%)$ for $\mathrm{H} 9$, and $60(8 \%)$ for H5. Shops that slaughtered poultry, kept poultry overnight, remained open without rest days, had uneven muddy floors, held poultry on the floor, and housed sick and healthy poultry together were more frequently positive for influenza A viruses. Reported monthly cleaning seemed protective, but disinfection practices were not otherwise associated with influenza A virus detection. Slaughtering, keeping poultry overnight, weekly rest days, infrastructure, and disinfection practices could be targets for interventions to reduce environmental contamination.
\end{abstract}

$\mathrm{H}$ ighly pathogenic avian influenza A(H5N1) virus causes outbreaks in poultry and sporadic infections in humans globally $(1,2)$. H5N1 virus is endemic to poultry in several countries in Southeast Asia,

Author affiliations: icddr,b, Dhaka, Bangladesh (S. Chowdhury, M.Z. Rahman, M.E. Hossain, P.K. Ghosh, S.S.U. Ahmed,

K. Sturm-Ramirez, E.S. Gurley); Chattogram Veterinary and Animal Sciences University, Chattogram, Bangladesh (S. Chowdhury, M.A. Hoque); Centers for Disease Control and Prevention, Atlanta, Georgia, USA (E. Azziz-Baumgartner, J.C. Kile, E.D. Kennedy, K. Sturm-Ramirez); Johns Hopkins Bloomberg School of Public Health, Baltimore, Maryland, USA (E.S. Gurley)

DOI: https://doi.org/10.3201/eid2609.191029 including Bangladesh, and causes major economic loss, as well as human illness and death $(1,3-5)$. During 2007-2018, Bangladesh reported >550 highly pathogenic avian influenza outbreaks in poultry, $90 \%$ of which were reported from commercial poultry farms (2). Since 2008, eight human H5N1 cases, including 1 death, have been reported in Bangladesh; 3 of these cases were in live bird market (LBM) workers presumably exposed to infected poultry in the LBM (1). Vietnam, Thailand, Indonesia, Hong Kong, China, and Cambodia have also reported human cases of H5N1 infection with a history of poultry exposure in LBMs, suggesting that LBMs can facilitate spread of H5N1 infection among poultry and from poultry to humans $(6,7)$.

Bangladesh has a large number of LBMs in urban areas in which multiple poultry species from backyard and commercial farms are housed together for sale; several studies detected highly pathogenic and low pathogenicity avian influenza viruses (AIVs) in LBM poultry and the environment (8-13). An LBM-based surveillance detected AIVs in waterfowl $(4 \%)$ and environmental samples from poultry markets (29\%). During 2007-2012, many subtypes, including H5N1, H5N2, H7N9, and H9N2, were identified in waterfowl and environmental samples (14). In 1 study, 9 (2\%) of 450 LBM workers from 12 LBMs across Bangladesh had antibodies against H5N1 virus (15). Such findings suggest that environmental contamination with AIVs occurs in Bangladesh and that poultry workers are at risk for contracting AIVs from infected poultry in LBMs and their contaminated environment.

Affected countries have introduced interventions to reduce the spread of AIVs in LBMs, including 
temporary or permanent LBM closure, banning overnight poultry storage, and mandatory rest day(s), as well as daily cleaning of surfaces to reduce environmental contamination (16-22). Temporary, weekly 1-day closures at live poultry markets in Guangzhou, China, was implemented for effective disinfection in response to the H7N9 outbreaks during 2013-2014 (23). However, market-level interventions have not been effective in reducing environmental contamination in Bangladesh. The infrastructure and daily activities of individual poultry shops within markets are heterogeneous (9). Because individual poultry shops have their own infrastructure and biosecurity controls, shop-level analyses might be useful in developing and designing effective interventions. Our study aimed to assess the shop-level prevalence of influenza A virus contamination among LBM shops across Bangladesh and to identify biosecurity and hygiene practices that are associated with risk for and protection from influenza A virus contamination.

\section{Methods}

Bangladesh has 10 metropolitan areas where large numbers of LBMs are located. We conducted a crosssectional study in all 10 areas (Figure 1).

\section{Selection of LBMs and Poultry Shops}

We determined that we needed 800 poultry shops to detect $\geq 1 \%$ prevalence of AIV with $95 \%$ confidence and $0.7 \%$ precision. Initially, the field team visited each metropolitan area to identify all LBMs and count the number of individually owned poultry shops in each market. After visiting all the cities, we prepared a list of LBMs with $\geq 10$ poultry shops for each

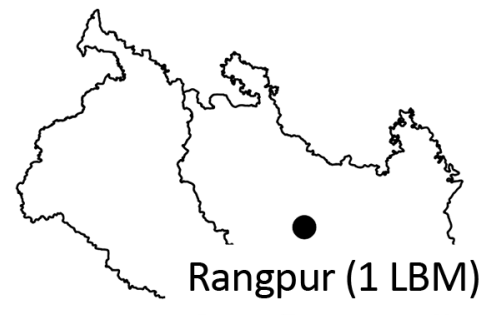

Figure 1. Locations of LBMs, 10 metropolitan areas, Bangladesh, March 2015. LBM, live bird market.

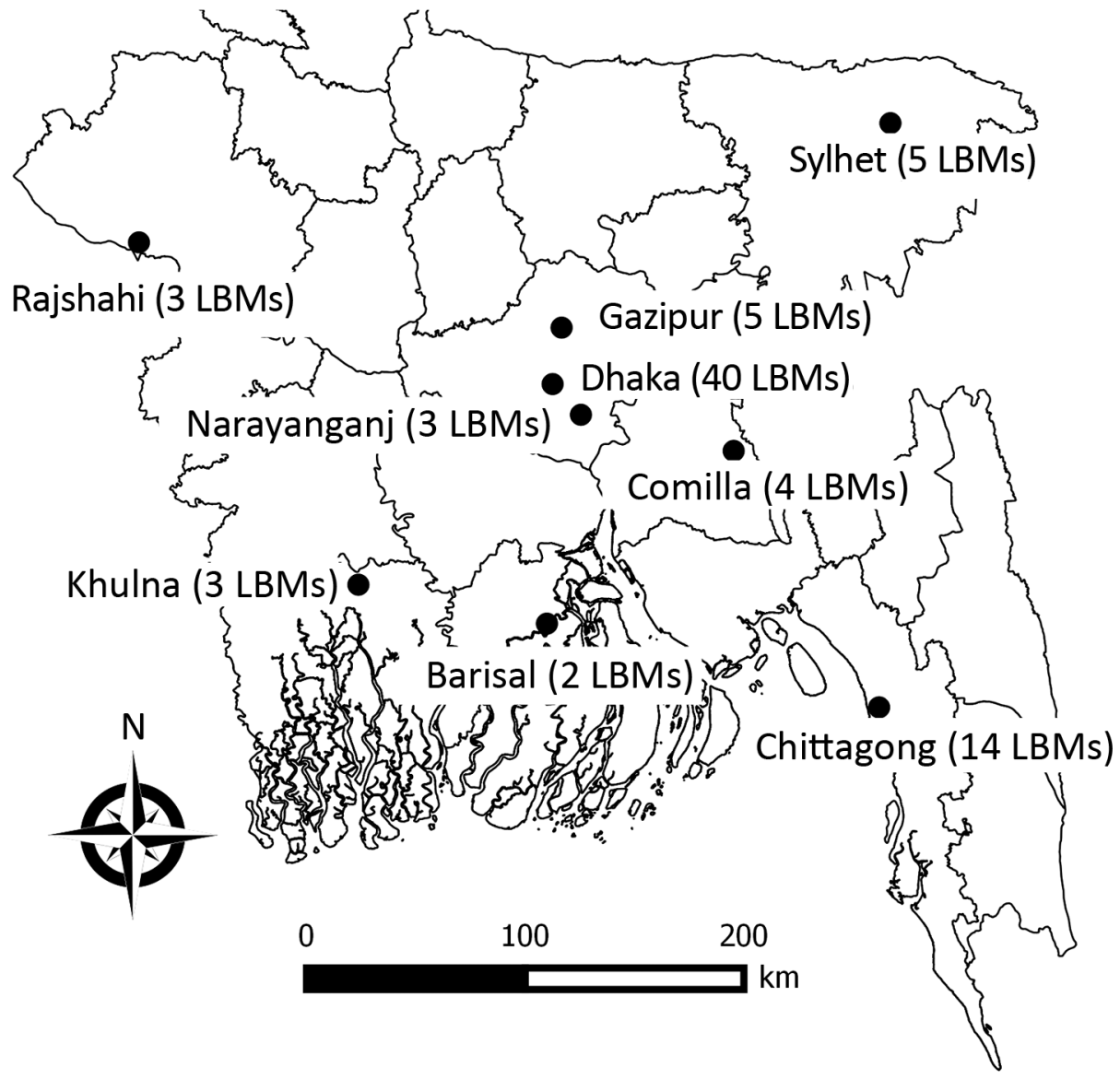


metropolitan area. We then selected 80 LBMs from 10 metropolitan areas by using a proportionate random sampling technique. Finally, we enrolled 10 shops in each LBM by using a random number generator.

\section{Biosecurity Measures and Other Practices}

During March 2015, the field team visited each selected shop to interview poultry shop owners or workers and collect information about shop characteristics, poultry transactions, and biosecurity and hygiene practices. On the basis of previously identified risk factors and recommended biosecurity and hygiene practices, we hypothesized that cleaning, disinfection, overnight poultry storage, a weekly rest day, practice of poultry slaughtering within shops, type of floor, poultry holding areas, presence of waterfowl, poultry density, number of poultry species, source of poultry, and the separation of sick poultry from healthy poultry could be associated with the detection of AIV in the poultry shop environment (Appendix 1, https:/ / wwwnc.cdc.gov/EID/article/26/9/19-1029-App1. pdf) $(11,17,19,21,22,24-28)$. In a questionnaire (Appendix 2, https:// wwwnc.cdc.gov/EID/article/26/9/191029-App2.pdf), we defined cleaning as "cleaning of poultry holding areas with water and/or broom," and we defined disinfection as "cleaning of poultry holding areas with a disinfectant." We asked owners whether they cleaned poultry holding areas daily, weekly, monthly, or did not clean within the past month. We asked whether they disinfected poultry holding areas weekly, monthly, or did not disinfect within the last month. The field team also collected some marketlevel information by interviewing members of the market committee.

\section{Sample Collection}

From each selected shop, we collected 8-10 swab specimens of poultry droppings, cages, feed, drinking water, slaughtering surfaces and utensils, slaughtering by-products, offal, shop floors, or waste bins. We pooled the 8-10 samples from each shop and tested them as a single sample. Some shops had no slaughtering facilities within their premises. From these shops, we collected swab specimens from other sources, including poultry droppings, cages, feed, and drinking water. We collected 1 pooled sample from each of 800 selected shops during March 2015 because highly pathogenic avian influenza (H5N1) activity typically peaks during January-March (29).

\section{Laboratory Testing}

We used a real-time reverse transcription PCR detection kit for typing and subtyping influenza viruses and fluorescent TaqMan probes at the icddr,b (30). Primers and probes specific for the matrix gene were used to detect influenza A viruses. To identify H5, $\mathrm{H} 7$, and $\mathrm{H} 9$ subtypes in influenza A virus-positive samples, we used H5, H7, and H9 hemagglutinin gene-specific primers and probes (30).

\section{Observations}

On the basis of laboratory testing results, we identified all influenza A/H5-positive shops and an equal number of influenza A virus-negative shops by using a random number generator and a list of influenza A virusnegative shops. Field staff observed each selected shop for a 3-hour period during April 2015. Staff observed cleaning and disinfection activities of selected poultry shops during surprise visits at times when cleaning activities were scheduled. Field staffs were blinded to the laboratory test results of selected shops.

\section{Statistical Analysis}

We summarized characteristics of poultry shops, including infrastructure and biosecurity and hygiene measures, by using descriptive analyses. We estimated the presence of environmental contamination with influenza A viruses in shops and 95\% CIs. Initially, we constructed a conceptual framework to identify causal association and confounders as described (31) (Figure 2). We then performed univariate analyses to estimate odds ratios (ORs). Exposure variables associated with outcomes with $p \leq 0.2$ in univariate analysis and confounder variables from the conceptual framework were selected for multivariate analyses. We used backward stepwise selection of variables with a significance level of 0.05 to construct models. We then used mixed-effect logistic regression multivariate models, accounting for clustering by metropolitan area and market, to estimate adjusted ORs (aORs). We assessed collinearity by calculating the variance inflation factor for independent variables used in the regression models (32). Weekly cleaning was highly correlated with daily cleaning practices; therefore, we removed weekly cleaning from the model during multivariate analyses. We calculated model $\chi^{2}$ and $\mathrm{R}^{2}$ (the coefficient of determination) to measure goodness-of-fit for multivariate regression model. We performed all statistical analyses by using Stata version 13 software (StataCorp LLC, https:/ / www.stata.com).

\section{Ethics}

Field staff obtained written consent from shop owners or poultry workers for data and sample collection from their shops. The icddr,b Research Review Committee 


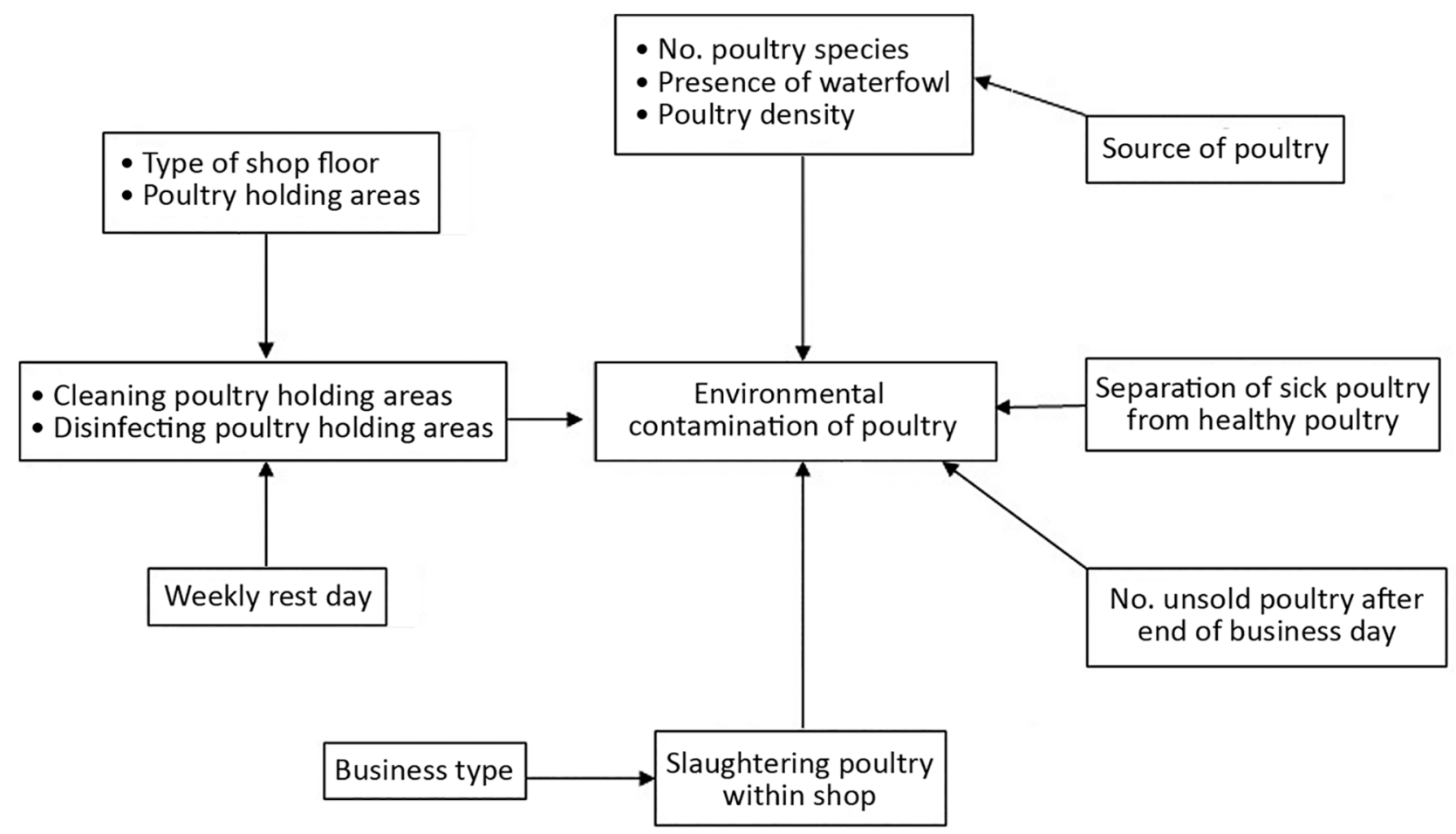

Figure 2. Conceptual framework for shop-level environmental contamination with avian influenza viruses in live bird markets, Bangladesh, March 2015.

and Ethical Review Committee reviewed and approved the study protocol (protocol no. PR-15012).

\section{Results}

We identified 104 LBMs that had $\geq 10$ poultry shops. Among these LBMs, we selected 800 shops in 80 LBMs for sample and data collection (Table 1). The average number of poultry shops in each market was 20 (SD 10.5 , range $10-55)$. Most (77\%) poultry shops were retail and sold live poultry directly to consumers. The average size of each poultry shop was $9 \mathrm{~m}^{2}$, and the average duration of trade per day was 14 hours. Chickens were the predominant poultry species sold at LBMs, and $91 \%$ of shops had a $>1$ poultry species the day of our visit (Table 2). A total of $6 \%$ of shops sold waterfowl only, and $4 \%$ sold chickens and ducks.

Poultry shopkeepers housed poultry in different types of settings, including wire cages, bamboo cages, and on the floor. Most $(80 \%)$ poultry shops had uneven floor surfaces, partially made with tiles/concrete and mud. Poultry shop owners collected poultry from different sources, including wholesale markets, intermediaries, and directly from poultry farms. Most (86\%) poultry shops slaughtered poultry on premises. Cleaning and disinfecting practices varied among poultry shops: 468 shops $(59 \%)$ reported cleaning poultry holding areas daily, $185(23 \%)$ reported using a disinfectant once a week, 592 (74\%) reported frequently working throughout the week (i.e., not following the recommended weekly day of rest), and 654 shops $(82 \%)$ reported keeping unsold poultry after the end of each business day.

\section{Laboratory Results for Environmental Specimens}

Environmental specimens from 205 (26\%, 95\% CI $23 \%-29 \%$ ) shops were positive for influenza A viral RNA; 108 (14\%, 95\% CI 11\%-16\%) were positive for the H9 subtype and 60 (8\%, 95\% CI 6\%-9\%) were positive for the $\mathrm{H} 5$ subtype (Table 1). An additional 37 (5\%, 95\% CI 3\%-6\%) influenza A-positive shops had samples that were not subtypeable with $\mathrm{H} 5, \mathrm{H} 7$, and H9 primers. Samples from 29 (4\%) shops were confirmed for both $\mathrm{H} 5$ and $\mathrm{H} 9$ subtypes. No samples were positive for $\mathrm{H} 7$ (95\% CI $0 \%-0.5 \%)$. Shops in all 10 cities had at $\geq 1$ sample positive for influenza $A$ viral RNA, and 7 cities (70\%) had shops positive for the H5 subtype. Among the $80 \mathrm{LBMs}, \geq 1$ shop from 74 markets $(93 \%)$ was positive for influenza A viral RNA, and $\geq 1$ shop from 35 markets $(44 \%)$ was positive for influenza A/H5 RNA. Environmental samples from 6 LBMs (3 from Chittagong, 1 from Dhaka, 1 from Khulna, and 1 from Comilla) were negative for influenza A viral RNA. 
Table 1. Influenza A and avian influenza virus contamination of live bird market shops, by metropolitan area, Bangladesh, March 2015

\begin{tabular}{|c|c|c|c|c|c|}
\hline Metropolitan cities & $\begin{array}{l}\text { No. live bird markets } \\
\text { investigated }\end{array}$ & $\begin{array}{c}\text { Total no. } \\
\text { shops tested }\end{array}$ & $\begin{array}{l}\text { No. (\%) shops positive } \\
\text { for influenza A }\end{array}$ & $\begin{array}{l}\text { No. (\%) shops positive } \\
\text { for influenza } \mathrm{A} / \mathrm{H} 5\end{array}$ & $\begin{array}{l}\text { No. }(\%) \text { shops positive } \\
\text { for influenza A/H9 }\end{array}$ \\
\hline Dhaka & 40 & 400 & $116(29)$ & $46(12)$ & $52(13)$ \\
\hline Chittagong & 14 & 140 & $15(12)$ & $3(2)$ & 7 (5) \\
\hline Gazipur & 5 & 50 & $14(28)$ & $1(2)$ & $9(18)$ \\
\hline Sylhet & 5 & 50 & $25(50)$ & $2(4)$ & $21(42)$ \\
\hline Comilla & 4 & 40 & $5(13)$ & 0 & $3(8)$ \\
\hline Rajshahi & 3 & 30 & $7(23)$ & $1(3)$ & $4(13)$ \\
\hline Khulna & 3 & 30 & $3(10)$ & 0 & $2(7)$ \\
\hline Narayanganj & 3 & 30 & $10(33)$ & $4(13)$ & $5(17)$ \\
\hline Barisal & 2 & 20 & $5(25)$ & 0 & $3(15)$ \\
\hline Rangpur & 1 & 10 & $5(50)$ & $3(30)$ & $2(20)$ \\
\hline Total & 80 & 800 & $205(26)$ & $60(8)$ & $108(14)$ \\
\hline
\end{tabular}

\section{Observational Findings}

We conducted observations in 60 influenza A/H5 virus-positive and 60 influenza A virus-negative shops. We did not find any major differences in cleaning and disinfection practices between influenza A/H5 virus-positive and influenza A virusnegative shops. Surveyors observed cleanings in $85 \%$ of influenza A/H5 virus-positive shops and $86 \%$ of influenza A virus-negative shops. Among these shops, only $2 \%$ of influenza A/H5 viruspositive shops performed disinfection by using washing powder or another recognized disinfectant, whereas $3 \%$ of influenza A virus-negative shops performed disinfection during our period of observation.

\section{Associations between Shop-Level Biosecurity, Hy- giene, and AIV Environmental Surface Contamination with Influenza A Viruses}

We showed by using univariate analyses that poultry shops that kept poultry on the floor (OR 3.86, 95\% C: 1-15.07; $\mathrm{p}=0.05)$, slaughtered poultry within the shop (OR 1.7, 95\% CI 1.08-2.67; p = 0.02 ), had unsold poultry after the end of the business day (OR 2.29, 95\% CI 1.44-3.63; p<0.01), did not rest 1 day a week (OR 1.34,95\% CI 1.14-1.58; $\mathrm{p}=0.01)$, kept sick and healthy appearing poultry together (OR 1.25, 95\% CI 1-1.58; p = 0.05), and had uneven floor surfaces (partly made with tiles/concrete and mud) (OR 4.01, 95\% CI 2.53-6.36; $\mathrm{p}<0.01$ ) were more likely to be positive for influenza A viral RNA in environmental samples compared with shops that did not have these characteristics (Table
3). Poultry shops that reportedly cleaned poultry holding areas either daily (OR $0.41,95 \%$ CI $0.27-$ 0.62 ; $\mathrm{p}<0.01$ ), weekly (OR 0.37, 95\% CI 0.18-0.73; $\mathrm{p}<0.01$ ), or monthly (OR $0.2,95 \%$ CI $0.08-0.49$; $\mathrm{p}<0.01$ ), and had weekly disinfection (OR 0.81, 95\% CI 0.61-1.07; $p=0.14$ ) seemed less likely to be positive for influenza A viral RNA compared with shops that did not.

In the final multivariate analysis model, we showed that poultry shops that slaughtered poultry within the shop (aOR 1.87, 95\% CI 1.11-3.14; $\mathrm{p}=$ 0.01 ), had unsold poultry after the end of the business day (aOR 2.35, 95\% CI 1.4-3.93; p<0.01), did not rest 1 day a week (aOR 1.35, 95\% CI 1.12-1.63; $\mathrm{p}<0.01$ ), had uneven floor surfaces (partly made with tiles/concrete and mud) (aOR 3.64, 95\% CI $2.32-5.71 ; \mathrm{p}<0.01$ ), held poultry on the floor (aOR $3.95,95 \%$ CI 1.27-12.23; $p=0.01$ ), and kept sick and healthy appearing poultry together (aOR 1.31, 95\% CI 1.06-1.62; $p=0.01$ ) were significantly more likely to be positive for influenza A viruses compared with shops that did not report these characteristics (Table 3). Reported monthly cleaning was protective (aOR $0.47,95 \%$ CI $0.28-0.8 ; \mathrm{p}<0.01$ ), but disinfecting practices of poultry holding areas was still not significantly associated with influenza A virus detection in the multivariate model $(p=0.85)$. The final model selected seemed to fit data well $\left(\chi^{2} 76.29\right.$, df $11, p<0.001$, and $\left.R^{2} 0.596\right)$. No market-level factors, including central cleaning and disinfection practices, were significantly associated with influenza A virus detection in the multivariate model (Appendix 1).

\begin{tabular}{lcccc}
\hline \multicolumn{3}{l}{ Table 2. Daily poultry trade at 800 live bird market shops selected for the study, by poultry species, Bangladesh, March 2015 } \\
\cline { 3 - 5 } Poultry sold & & \multicolumn{4}{c}{ Mean no. poultry/day (range) } \\
\cline { 3 - 5 } Only chicken & No. (\%) shops & Stocked/day & Sold/day & Leftover/day \\
Only waterfowl & $722(90)$ & $210(20-3,760)$ & $159(10-3,760)$ & $52(0-1,650)$ \\
Only pigeon & $3(1)$ & $130(50-290)$ & $108(32-252)$ & $22(10-38)$ \\
Two poultry species & $5(1)$ & $90(50-150)$ & $41(5-80)$ & $49(30-70)$ \\
More than 2 poultry species & $57(7)$ & $267(20-1333)$ & $185(10-850)$ & $83(5-895)$ \\
\hline
\end{tabular}




\section{Discussion}

Evaluation of existing biosecurity and hygiene practices is necessary to develop and design interventions to reduce the spread of AIVs in LBMs. Our study provides a detailed depiction of the daily operation of poultry shops and current biosecurity and hygiene practices in selected LBMs of Bangladesh. We identified certain biosecurity and hygiene practices associated with environmental contamination with AIVs: slaughtering poultry within shops, having unsold poultry after the end of the business day, skipping rest days, uneven floor surfaces, holding poultry on the floor, and keeping sick and healthy appearing poultry together.

Our study determined that most shops did not implement biosecurity practices, which have reduced AIV in other countries. For example, biosecurity and hygiene practices, including weekly rest days, depopulation, and cleaning with disinfectant, reduced the risk for AIV detection in poultry and environmental specimens in China (28). The prevalence of H7N9 virus in environmental specimens

Table 3. Shop-level biosecurity practices and environmental contamination with 800 influenza A viruses in 10 metropolitan areas, Bangladesh, March 2015*

\begin{tabular}{|c|c|c|c|c|c|c|}
\hline Variable & $\begin{array}{l}\text { No. (\%) } \\
\text { shops }\end{array}$ & $\begin{array}{c}\text { No. }(\%) \text { shops } \\
\text { positive for influenza } \\
\text { A viruses, } n=205\end{array}$ & OR $(95 \% \mathrm{Cl})$ & $\mathrm{p}$ value & $\begin{array}{c}\text { Adjusted OR } \\
(95 \% \mathrm{Cl}) \dagger\end{array}$ & $\mathrm{p}$ value $†$ \\
\hline \multicolumn{7}{|l|}{ Poultry species } \\
\hline Single & $731(91)$ & $184(25)$ & Referent & NA & & \\
\hline Multiple & $69(9)$ & $21(30)$ & $1.45(0.9-2.32)$ & 0.12 & & \\
\hline \multicolumn{7}{|l|}{ Presence of waterfowl } \\
\hline No & $752(94)$ & $190(25)$ & Referent & NA & & \\
\hline Yes & $48(6)$ & $15(31)$ & $1.68(0.86-3.32)$ & 0.13 & & \\
\hline \multicolumn{7}{|l|}{ Poultry holding areas } \\
\hline Only wire cage & $281(35)$ & $55(20)$ & Referent & NA & Referent & NA \\
\hline Only bamboo cage & $153(19)$ & $53(35)$ & $2.12(0.85-5.28)$ & 0.1 & $2.24(0.87-5.77)$ & 0.09 \\
\hline Only floor & $24(3)$ & $9(38)$ & $3.86(1-15.07)$ & 0.05 & $3.95(1.27-12.23)$ & 0.01 \\
\hline Mixed & $342(43)$ & $88(26)$ & $1.72(0.96-3.09)$ & 0.06 & $1.71(0.96-3.04)$ & 0.06 \\
\hline \multicolumn{7}{|l|}{ Cleaning poultry holding areas } \\
\hline No cleaning in past month & $26(3)$ & $12(46)$ & Referent & NA & Referent & NA \\
\hline Monthly & $68(9)$ & $10(14)$ & $0.2(0.08-0.49)$ & $<0.01$ & $0.47(0.28-0.8)$ & $<0.01$ \\
\hline Weeklył & $238(30)$ & $57(24)$ & $0.37(0.18-0.73)$ & $<0.01$ & NA & NA \\
\hline Daily & $468(59)$ & $126(27)$ & $0.41(0.27-0.62)$ & $<0.01$ & $1.09(0.91-1.31)$ & 0.31 \\
\hline \multicolumn{7}{|l|}{ Disinfecting poultry holding areas } \\
\hline No disinfection in past month & $577(72)$ & $150(26)$ & Referent & NA & & \\
\hline Monthly & $38(5)$ & $10(26)$ & $1.1(0.53-2.25)$ & 0.79 & & \\
\hline Weekly & $185(23)$ & $45(24)$ & $0.81(0.61-1.07)$ & 0.14 & & \\
\hline \multicolumn{7}{|l|}{ Slaughtering poultry within shop } \\
\hline No & $115(14)$ & $18(16)$ & Referent & NA & Referent & NA \\
\hline Yes & $685(86)$ & $187(27)$ & $1.7(1.08-2.67)$ & 0.02 & $1.87(1.11-3.14)$ & 0.01 \\
\hline \multicolumn{7}{|c|}{ Presence of unsold poultry after the end of business day } \\
\hline No poultry left & $146(18)$ & $19(13)$ & Referent & NA & Referent & NA \\
\hline Presence of unsold poultry & $654(82)$ & $186(28)$ & $2.29(1.44-3.63)$ & $<0.01$ & $2.35(1.4-3.93)$ & $<0.01$ \\
\hline \multicolumn{7}{|l|}{ Weekly rest day } \\
\hline Yes & $208(26)$ & $51(25)$ & Referent & NA & Referent & NA \\
\hline No & $592(74)$ & $154(26)$ & $1.34(1.14-1.58)$ & $<0.01$ & $1.35(1.12-1.63)$ & $<0.01$ \\
\hline \multicolumn{7}{|l|}{ Source of poultry } \\
\hline Poultry farm & $49(6)$ & $12(24)$ & Referent & NA & & \\
\hline Intermediaries & $54(7)$ & $10(19)$ & $0.85(0.27-2.64)$ & 0.78 & & \\
\hline Wholesale market & $525(66)$ & $143(27)$ & $1.05(0.51-2.16)$ & 0.88 & & \\
\hline Multiple sources & $172(21)$ & $40(23)$ & $0.94(0.35-2.49)$ & 0.9 & & \\
\hline \multicolumn{7}{|c|}{ Separation of sick poultry from healthy flocks } \\
\hline Yes & $357(45)$ & $85(24)$ & Referent & NA & Referent & NA \\
\hline No & $443(55)$ & $120(27)$ & $1.25(1-1.58)$ & 0.05 & $1.31(1.06-1.62)$ & 0.01 \\
\hline \multicolumn{7}{|l|}{ Type of shop floor } \\
\hline Tiles/concrete & $244(31)$ & 32 (13) & Referent & NA & Referent & NA \\
\hline Dirt/mud & $33(4)$ & $8(24)$ & $3.61(1.7-7.67)$ & $<0.01$ & $3.2(1.46-7.09)$ & $<0.01$ \\
\hline Mixed & $523(65)$ & $165(32)$ & $4.01(2.53-6.36)$ & $<0.01$ & $3.64(2.32-5.71)$ & $<0.01$ \\
\hline \multicolumn{7}{|l|}{ Poultry density $/ \mathrm{mm}^{2}$} \\
\hline$\leq 32$ & $568(71)$ & $147(26)$ & Referent & NA & & \\
\hline$\geq 33$ & $232(29)$ & $58(25)$ & $0.89(0.68-1.15)$ & 0.39 & & \\
\hline
\end{tabular}


from LBMs in China decreased after the closure of live poultry markets (33). Daily waste removal was found to be protective in Indonesia (17). In the United States, environmental contamination decreased after implementing routine cleaning and disinfection $(19,22)$. Although monthly cleaning was found to be protective in reducing environmental contamination with AIVs in this study, most shops in Bangladesh do not disinfect, and their current biosecurity practices do not seem to prevent environmental contamination. Moreover, most of the studied shops had rough dirt and mud floors that are less suitable for proper cleaning and disinfection, indicating poor market infrastructure.

Globally, countries reporting human cases of AIV also have LBMs contaminated with AIVs. AIV contamination of LBM environments increases the risk for infection and amplification of the virus in virusfree birds. In addition, if the AIV is zoonotic, as are H7N9, H5N1, and H5N6 viruses, increased viremia in birds increases the risk for human exposure and infection. For example, in Vietnam, AIVs were detected in $3.2 \%$ of poultry specimens collected from LBMs; in Egypt, H5N1 virus was detected in poultry in $12.4 \%$ of LBMs; in China, H7N9 virus was detected in $10 \%$ of environmental specimens from LBMs; in Indonesia, AIVs were detected in $47 \%$ of environmental specimens from LBMs; in Thailand, H5N1 virus was detected in $3.1 \%$ of market poultry; and in Bangladesh, AIVs were detected in $23 \%$ of poultry specimens $(10,17,33-35)$. In our study, $>90 \%$ of the LBMs were positive for influenza A viruses, and $44 \%$ were specifically positive for AIV H5 RNA. Detection of AIV RNA in environmental samples indicates that market poultry were infected with AIVs near the time of sample collection and might excrete, secrete, or contaminate surfaces and humans through their carcasses, feathers, and offal. Our study findings also confirmed the presence of 2 subtypes (H5 and H9) of AIV, which might lead to genetic reassortment and evolution of new AIV strains in poultry of public health concern (29).

Epidemiologic studies have described the effectiveness of weekly or monthly rest days in reducing environmental contamination of LBMs with AIV $(21,24)$. The number of human cases of infection with H7N9 virus has been observed to be reduced after permanent or temporary closure of LBMs and the culling of poultry $(24,25,33,36)$. The government of Bangladesh imposed an order in 2012 to practice weekly rest days for cleaning and disinfecting LBMs within Dhaka (37). Nevertheless, 1 study found $74 \%$ of poultry shop owners did not practice weekly rest days, which might increase the risk for environmental contamination. A weekly rest day should be enforced by the government to decrease the risk for AIV circulation in LBMs.

Unsold poultry can play a major role in maintaining virus circulation in markets (25). Unsold infected poultry can infect incoming poultry, promoting further transmission of influenza viruses in susceptible birds. Banning overnight poultry storage in China reduced H9N2 virus isolation in chickens (84\%) (24). In our study, most $(82 \%)$ poultry shops reported that they stored poultry overnight in their shops to sell the next day. A previous study from Bangladesh also found that $73 \%$ of poultry shops kept poultry in their stalls for $>1$ day (38).

Slaughtering by-products, such as blood and offal, of AIV-infected poultry provide the most likely opportunity for environmental contamination and subsequent human exposure to high loads of virus. In Indonesia, slaughtering poultry within market premises was a risk factor for environmental contamination $(17,26)$. H7N9 virus was detected in swab samples collected from surfaces of chopping boards in China (33). Persons from China and Bangladesh prefer to purchase live chickens that are slaughtered in the market at the time of purchase $(9,36)$. A study suggested introducing central slaughtering of all live poultry in the LBM to control the risk posed of AIVs (39). In Bangladesh, most poultry shops, including those in this study, sold and slaughtered poultry within their shop (9). This practice might increase the risk for AIV contamination and perpetuate the exposure of poultry to AIV in LBMs. Although our study did not assess AIV transmission within LBMs, we cannot rule out the risk for AIV transmission to humans through slaughtering of infected poultry. We recommend introducing centralized slaughter facilities in LBMs to decrease the spread of AIV.

LBMs in Bangladesh are larger (ranging from 10 to 55 poultry shops) than those in Hong Kong, where the number of poultry shops in each LBM was 3-24 (21). Maintaining effective biosecurity and hygiene measures might be more difficult in larger LBMs that had poor infrastructure. The infrastructures of LBMs in city areas were quite similar. However, the prevalence of $\mathrm{H} 5$ and $\mathrm{H} 9$ subtypes varied between cities and might naturally differ in virus ecology by farm or geographic site. The infrastructure of our studied poultry shops within LBMs was often rudimentary: most were fully enclosed by walls, but most had rough muddy floors, unsystematic poultry holding areas, poor waste disposal systems, and unconfined slaughtering facilities. Urban markets have more 
poultry shops than rural markets. Urban LBMs usually are open every day, whereas rural LBMs are open once or twice per week. Bangladesh should consider investing in poultry shop infrastructure improvements and biosecurity practices, particularly in city areas, to better control environmental contamination with AIVs.

In China, poultry trading networks linked with LBMs were strongly associated with a higher prevalence of H7N9 virus among poultry and risk for H7N9 transmission to humans (36). Movement of infected poultry between markets has a major role in the spread of AIVs from 1 market to another $(17,40)$. Poultry market supply chains in urban areas of Bangladesh are complex, collecting poultry from different sources, including directly from farms, intermediaries, or wholesale markets. These complex networks might promote a high number of contacts between infected and susceptible marketed birds and, therefore, increase AIV transmission potential within the trade networks.

This cross-sectional study design might have limited interpretation of some of the results. Although AIV circulation and amplification at LBMs are continuous processes influenced by time-dependent parameters, such as time to last cleaning before sampling and time to last poultry introduction/mixing before sampling, we only examined environmental contamination for AIVs at 1 point in time and did not explore time from last cleaning or disinfection. No additional laboratory tests were performed to characterize viral load and viability of AIVs detected because of limited funding. Therefore, it is unclear if the AIVs detected during the study were infectious to humans. The information we collected from poultry shop owners and workers about biosecurity might have been affected by social desirability bias, which might have underestimated the prevalence of practices that place shop at risk for contamination with AIVs.

In conclusion, our study identified risky practices, hygiene, and infrastructure in Bangladesh LBMs associated with an increased likelihood of shop contamination with AIVs. Improvement of these biosecurity practices, such as removing poultry at the end of the day, observing weekly rest days, introducing centralized slaughter facilities, and regular cleaning and disinfection, might help to prevent AIV contamination. LBM infrastructure, including floors, poultry holding areas, waste disposal systems, and slaughtering facilities, also need improvement. Potential valuable shop-level interventions to address these deficiencies in biosecurity practices might include training for poultry shop owners and poultry workers about effective biosecurity practices to reduce AIV contamination and the risk AIV poses to humans in Bangladesh.

\section{Acknowledgments}

We thank Susan C. Trock and Nord Zeidner for providing scientific input during protocol development, Gladys Leterme for proofreading and editing the manuscript, and field staff for their efforts during sample and data collection. The icddr, $b$ is also grateful to the governments of Bangladesh, Canada, Sweden, and the United Kingdom for providing core/unrestricted support and acknowledge with gratitude the commitment of the Centers for Disease Control and Prevention to its research efforts.

This study was supported by the Centers for Disease Control and Prevention (cooperative agreement no. 1U01GH001207-01).

\section{About the Author}

Dr. Chowdhury is a veterinary epidemiologist at the icddr,b, Dhaka, Bangladesh. His primary research interests are epidemiology, infectious diseases surveillance, antimicrobial drug resistance, food safety, public health advocacy, and One Health issues.

\section{References}

1. World Health Organization. Cumulative number of confirmed human cases of avian influenza $\mathrm{A}(\mathrm{H} 5 \mathrm{~N} 1)$ reported to $\mathrm{WHO}$, 2019 [cited 2020 May 18]. https:/ / www.who.int/influenza/ human_animal_interface/2019_02_12_tableH5N1.pdf

2. World Organisation for Animal Health. Update on avian influenza in animals (types H5 and H7), 2018 [cited 2020 May 18]. http:/ / www.oie.int/en/animal-health-in-the-world/ update-on-avian-influenza/2018

3. Rushton J, Viscarra R, Bleich EG, McLeod A. Impact of avian influenza outbreaks in the poultry sectors of five South East Asian countries (Cambodia, Indonesia, Lao PDR, Thailand, Viet Nam) outbreak costs, responses and potential long term control. World's Poultry Science Journal. 2005;61:491-514. https:/ / doi.org/10.1079/WPS200570

4. Smith GJ, Naipospos TS, Nguyen TD, de Jong MD, Vijaykrishna D, Usman TB, et al. Evolution and adaptation of H5N1 influenza virus in avian and human hosts in Indonesia and Vietnam. Virology. 2006;350:258-68. https://doi.org/10.1016/j.virol.2006.03.048

5. Chowdhury S, Hossain ME, Ghosh PK, Ghosh S, Hossain MB, Beard C, et al. The pattern of highly pathogenic avian influenza H5N1 outbreaks in south Asia. Trop Med Infect Dis. 2019;4:138. https:/ / doi.org/10.3390/ tropicalmed 4040138

6. Wan X-F, Dong L, Lan Y, Long L-P, Xu C, Zou S, et al. Indications that live poultry markets are a major source of human H5N1 influenza virus infection in China. J Virol. 2011;85:13432-8. https://doi.org/10.1128/JVI.05266-11

7. Webster RG. Wet markets - a continuing source of severe acute respiratory syndrome and influenza? Lancet. 2004; 363:234-6. https://doi.org/10.1016/S0140-6736(03)15329-9 
8. Nakamura S, Maeda N, Miron IM, Yoh M, Izutsu K, Kataoka C, et al. Metagenomic diagnosis of bacterial infections. Emerg Infect Dis. 2008;14:1784-6. https://doi.org/10.3201/eid1411.080589

9. Biswas P, Giasuddin M, Nath B, Islam M, Debnath N, Yamage M. Biosecurity and circulation of influenza A (H5N1) virus in live bird markets in Bangladesh, 2012. Transbound Emerg Dis. 2015; 64:883-91.

10. Negovetich NJ, Feeroz MM, Jones-Engel L, Walker D, Alam SM, Hasan K, et al. Live bird markets of Bangladesh: H9N2 viruses and the near absence of highly pathogenic H5N1 influenza. PLoS One. 2011;6:e19311. https://doi.org/ 10.1371/journal.pone.0019311

11. Sayeed MA, Smallwood C, Imam T, Mahmud R, Hasan RB, Hasan M, et al. Assessment of hygienic conditions of live bird markets on avian influenza in Chittagong metro, Bangladesh. Prev Vet Med. 2017;142:7-15. https:/ / doi.org/ 10.1016/j.prevetmed.2017.04.009

12. Turner JC, Feeroz MM, Hasan MK, Akhtar S, Walker D, Seiler P, et al. Insight into live bird markets of Bangladesh: an overview of the dynamics of transmission of H5N1 and H9N2 avian influenza viruses. Emerg Microbes Infect. 2017;6:e12. https://doi.org/10.1038/emi.2016.142

13. Kim Y, Biswas PK, Giasuddin M, Hasan M, Mahmud R, Chang Y-M, et al. Prevalence of avian influenza A(H5) and $\mathrm{A}(\mathrm{H} 9)$ viruses in live bird markets, Bangladesh. Emerg Infect Dis. 2018;24:2309-16. https:/ / doi.org/10.3201/ eid2412.180879

14. Khan SU, Gurley ES, Gerloff N, Rahman MZ, Simpson N, Rahman M, et al. Avian influenza surveillance in domestic waterfowl and environment of live bird markets in Bangladesh, 2007-2012. Sci Rep. 2018;8:9396. https:/ / doi.org/ 10.1038/s41598-018-27515-w

15. Nasreen S, Khan SU, Luby SP, Gurley ES, Abedin J, Zaman RU, et al. Highly pathogenic avian influenza $\mathrm{A}(\mathrm{H} 5 \mathrm{~N} 1)$ virus infection among workers at live bird markets, Bangladesh, 2009-2010. Emerg Infect Dis. 2015;21:629-37. https://doi.org/ 10.3201/eid2104.141281

16. Kung NY, Guan Y, Perkins NR, Bissett L, Ellis T, Sims L, et al. The impact of a monthly rest day on avian influenza virus isolation rates in retail live poultry markets in Hong Kong. Avian Dis. 2003;47(Suppl):1037-41. https:// doi.org/ 10.1637/0005-2086-47.s3.1037

17. Indriani R, Samaan G, Gultom A, Loth L, Irianti S, Adjid R, et al. Environmental sampling for avian influenza virus A (H5N1) in live-bird markets, Indonesia. Emerg Infect Dis. 2010;16:1889-95. https://doi.org/10.3201/eid1612.100402

18. Murhekar M, Arima Y, Horby P, Vandemaele KA, Vong S, Zijian F, et al.; World Health Organization Regional Office for the Western Pacific Event Management Team. Avian influenza A(H7N9) and the closure of live bird markets. Western Pac Surveill Response J. 2013;4:4-7. https://doi.org/10.5365/wpsar.2013.4.2.008

19. Trock SC, Gaeta M, Gonzalez A, Pederson JC, Senne DA. Evaluation of routine depopulation, cleaning, and disinfection procedures in the live bird markets, New York. Avian Dis. 2008;52:160-2. https:// doi.org/10.1637/ 7980-040607-Reg

20. Fournié G, Guitian J, Desvaux S, Cuong VC, Dung H, Pfeiffer DU, et al. Interventions for avian influenza A (H5N1) risk management in live bird market networks. Proc Natl Acad Sci U S A. 2013;110:9177-82. https:/ / doi.org/10.1073/ pnas. 1220815110

21. Lau EH, Leung YH, Zhang LJ, Cowling BJ, Mak SP, Guan Y, et al. Effect of interventions on influenza A (H9N2) isolation in Hong Kong's live poultry markets, 1999-2005.
Emerg Infect Dis. 2007;13:1340-7. https:/ / doi.org/10.3201/ eid1309.061549

22. Bulaga LL, Garber L, Senne DA, Myers TJ, Good R, Wainwright $S$, et al. Epidemiologic and surveillance studies on avian influenza in live-bird markets in New York and New Jersey, 2001. Avian Dis. 2003;47(Suppl):996-1001. https://doi.org/10.1637/0005-2086-47.s3.996

23. Yuan J, Tang X, Yang Z, Wang M, Zheng B. Enhanced disinfection and regular closure of wet markets reduced the risk of avian influenza A virus transmission. Clin Infect Dis. 2014;58:1037-8. https:// doi.org/10.1093/cid/cit951

24. Leung YH, Lau EH, Zhang LJ, Guan Y, Cowling BJ, Peiris JS. Avian influenza and ban on overnight poultry storage in live poultry markets, Hong Kong. Emerg Infect Dis. 2012;18:1339-41. https://doi.org/10.3201/ eid1808.111879

25. Offeddu V, Cowling BJ, Malik Peiris JS. Interventions in live poultry markets for the control of avian influenza: a systematic review. One Health. 2016;2:55-64. https://doi.org/10.1016/j.onehlt.2016.03.002

26. Samaan G, Gultom A, Indriani R, Lokuge K, Kelly PM. Critical control points for avian influenza A H5N1 in live bird markets in low resource settings. Prev Vet Med. 2011;100:71-8. https:// doi.org/10.1016/j.prevetmed. 2011.03.003

27. Yuan J, Lau EH, Li K, Leung YH, Yang Z, Xie C, et al. Effect of live poultry market closure on avian influenza A(H7N9) virus activity in Guangzhou, China, 2014. Emerg Infect Dis. 2015;21:1784-93. https://doi.org/10.3201/ eid2110.150623

28. Yuan J, Tang X, Yang Z, Wang M, Zheng B. Enhanced disinfection and regular closure of wet markets reduced the risk of avian influenza A virus transmission. Clin Infect Dis. 2014;58:1037-8. https://doi.org/10.1093/cid/cit951

29. Durand LO, Glew P, Gross D, Kasper M, Trock S, Kim IK, et al. Timing of influenza $\mathrm{A}(\mathrm{H} 5 \mathrm{~N} 1)$ in poultry and humans and seasonal influenza activity worldwide, 2004-2013. Emerg Infect Dis. 2015;21:202-8. https://doi.org/10.3201/ eid2102.140877

30. Centers for Disease Control and Prevention. Laboratory support for influenza surveillance (CLSIS). Atlanta: The Centers; 2013.

31. Greenland S, Pearl J, Robins JM. Causal diagrams for epidemiologic research. Epidemiology. 1999;10:37-48. https://doi.org/10.1097/00001648-199901000-00008

32. Dormann CF, Elith J, Bacher S, Buchmann C, Carl G, Carré $\mathrm{G}$, et al. Collinearity: a review of methods to deal with it and a simulation study evaluating their performance. Ecography. 2013;36:27-46. https://doi.org/10.1111/ j.1600-0587.2012.07348.x

33. Wang X, Liu S, Mao H, Yu Z, Chen E, Chai C. Surveillance of avian H7N9 virus in various environments of Zhejiang Province, China before and after live poultry markets were closed in 2013-2014. PLoS One. 2015;10:e0135718. https://doi.org/10.1371/journal.pone.0135718

34. Nguyen DT, Bryant JE, Davis CT, Nguyen LV, Pham LT, Loth L, et al. Prevalence and distribution of avian influenza A(H5N1) virus clade variants in live bird markets of Vietnam, 2011-2013. Avian Dis. 2014;58:599-608. https://doi.org/10.1637/10814-030814-Reg

35. Abdelwhab EM, Selim AA, Arafa A, Galal S, Kilany WH, Hassan MK, et al. Circulation of avian influenza H5N1 in live bird markets in Egypt. Avian Dis. 2010;54:911-4. https://doi.org/10.1637/9099-100809-RESNOTE.1

36. Zhou X, Li Y, Wang Y, Edwards J, Guo F, Clements AC, et al. The role of live poultry movement and live bird market 
biosecurity in the epidemiology of influenza A (H7N9): a cross-sectional observational study in four eastern China provinces. J Infect. 2015;71:470-9. https:// doi.org/10.1016/ j.jinf.2015.06.012

37. Biswas PK, Giasuddin M, Nath BK, Islam MZ, Debnath NC, Yamage M. Biosecurity and circulation of influenza A (H5N1) virus in live bird markets in Bangladesh, 2012. Transbound Emerg Dis. 2017;64:883-91. https://doi.org/ $10.1111 /$ tbed.12454

38. Sarker S, Talukder S, Chowdhury E, Das P. Knowledge, attitudes and practices on biosecurity of workers in live bird markets at Mymensingh, Bangladesh. Journal of Agricultural and Biological Science. 2011;6:12-7.

39. Yu H, Wu JT, Cowling BJ, Liao Q, Fang VJ, Zhou S, et al. Effect of closure of live poultry markets on poultry-to-person transmission of avian influenza A H7N9 virus: an ecological study. Lancet. 2014;383:541-8. https://doi.org/ 10.1016/S0140-6736(13)61904-2

40. Van Kerkhove MD, Vong S, Guitian J, Holl D, Mangtani P, San S, et al. Poultry movement networks in Cambodia: implications for surveillance and control of highly pathogenic avian influenza (HPAI/H5N1). Vaccine. 2009; 27:6345-52. https://doi.org/10.1016/ j.vaccine.2009.05.004

Address for correspondence: Sukanta Chowdhury, Programme for Emerging Infections, International Centre for Diarrheal Diseases Research, Mohakhali 1212, Bangladesh; email: sukanta@icddrb.org or sukanta.icddrb@yahoo.com

\section{July 2020}

\section{Emerging Viruses}

- Case Manifestations and Public Health Response for Outbreak of Meningococcal W Disease, Central Australia, 2017

- Transmission of Chikungunya Virus in an Urban Slum, Brazil

- Public Health Role of Academic Medical Center in Community Outbreak of Hepatitis A, San Diego County, California, USA, 2016-2018

- Macrolide-Resistant Mycoplasma pneumoniae Infections in Pediatric Community-Acquired Pneumonia

- Efficient Surveillance of Plasmodium knowlesi Genetic Subpopulations, Malaysian Borneo, 2000-2018

- Bat and Lyssavirus Exposure among Humans in Area that Celebrates Bat Festival, Nigeria, 2010 and 2013

- Rickettsioses as Major Etiologies of Unrecognized Acute Febrile Illness, Sabah, East Malaysia

- Meningococcal W135 Disease Vaccination Intent, the Netherlands, 2018-2019

- Risk for Coccidioidomycosis among Hispanic Farm Workers, California, USA, 2018

- Atypical Manifestations of Cat-Scratch Disease, United States, 2005-2014

- Paradoxal Trends in Azole-Resistant Aspergillus fumigatus in a National Multicenter Surveillance Program, the Netherlands, 2013-2018

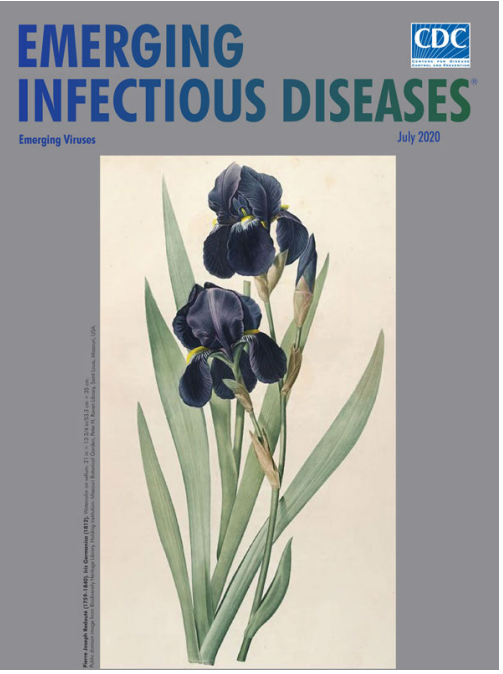

- Large Nationwide Outbreak of Invasive Listeriosis Associated with Blood Sausage, Germany, 2018-2019

- High Contagiousness and Rapid Spread of Severe Acute Respiratory Syndrome Coronavirus 2

- Severe Acute Respiratory Syndrome Coronavirus 2-Specific Antibody Responses in Coronavirus Disease Patients

- Transmission of Legionnaires' Disease through Toilet Flushing

- Burden and Cost of Hospitalization for Respiratory Syncytial Virus in Young Children, Singapore
- Human Adenovirus Type 55 Distribution, Regional Persistence, and Genetic Variability

- Policy Decisions and Use of Information Technology to Fight COVID-19, Taiwan

- Sub-Saharan Africa and Eurasia Ancestry of Reassortant Highly Pathogenic Avian Influenza A(H5N8) Virus, Europe, December 2019

- Serologic Evidence of Severe Fever with Thrombocytopenia Syndrome Virus and Related Viruses in Pakistan

- Survey of Parental Use of Antimicrobial Drugs for Common Childhood Infections, China

- Shuni Virus in Wildlife and Nonequine Domestic Animals, South Africa

- Identifying Locations with Possible Undetected Imported Severe Acute Respiratory Syndrome Coronavirus 2 Cases by Using Importation Predictions

- Carbapenem Resistance Conferred by OXA-48 in K2-ST86 Hypervirulent Klebsiella pneumoniae, France

- Laboratory-Acquired Dengue Virus Infection, United States, 2018

- Linking Epidemiology and Whole-Genome Sequencing to Investigate Salmonella Outbreak, Massachusetts, USA, 2018

- Possible Bat Origin of Severe Acute Respiratory Syndrome Coronavirus 2 